\title{
Formation of the Azygos Vein
}

\author{
Formación de la Vena Ácigos
}

\begin{abstract}
"Elton Correia Alves; "Wellington Rodrigues Porciúncula Junior; "** Rodrigo Freitas Monte Bispo; ****élio Fernando de Sousa-Rodrigues \& ${ }^{* * * * *}$ Amauri Clemente da Rocha
\end{abstract}

\begin{abstract}
ALVES, E. C.; PORCIÚNCULA JUNIOR, R. W.; MONTE BISPO, R. F.; DE SOUSA-RODRIGUES, C. F. \& DA ROCHA, A. C. Formation of the azygos vein. Int. J. Morphol., 29(1):140-143, 2011.

SUMMARY: The aim of the present study was to determine the most common origin of the azygos vein. Thirty cadavers male and female, white and non-white adult individuals of different ages fixed in $10 \%$ formaldehyde and dissected. All cadavers had an undisclosed clinical death and were donated to the Universidade Estadual de Ciências da Saúde de Alagoa s, Brazil. Eleven different formations were found. The right subcostal vein was was only observed in 13 cases (43.33\%); the azygos vein was formed by the confluence of the right subcostal and right ascending lumbar vein in three cases (10\%); by the right subcostal vein with a contribution from the inferior vena cava (IVC) in three cases (10\%); by the right subcostal with contribution from IVC and right ascending lumbar vein in three cases (10\%); by the right and left subcostal veins in two cases (6.66\%); by the right and left subcostal veins and contribution from the IVC in one case (3.33\%); by the right and left subcostal veins and left accessory renal vein in one case (3.33\%); by the left renal vein in one case $(3.33 \%)$; by the right subcostal and left gonadal veins with contribution from the IVC in one case (3.33\%); by the right subcostal and left renal veins in one case $(3.33 \%)$; and composed by the continuation of the 11 th posterior intercostal vein in one case $(3.33 \%)$. Based on the results, the right subcostal vein was the only structure with a significant presence in the formation of the azygos vein.
\end{abstract}

KEY WORDS: Azygos vein; Inferior vena cava inferior; Anatomy.

\section{INTRODUCTION}

The azygos vein is a vascular structure of extreme importance that drains blood from the posterior walls of the thorax and abdomen (Moore \& Dalley, 2001) and unites the superior vena cava (SVC) to the inferior vena cava (IVC). According to Woodburne (1984) and Williams et al. (1995), the azygos vein generally has imperfect, insufficient valves (Spalteholz, 1967), allowing collateral circulation in both directions in cases of thrombosis of the SVC and functioning as an alternative pathway for blood to arrive at the heart. There is also communication with the vertebral venous plexuses, which assists in collateral circulation.

The azygos vein is a blood vessel that originates most often in the abdominal region and ends in the thorax, where it empties into the SVC. Its formation is variable, occurring generally at the level of the first lumbar vertebra and commonly emerging from the confluence of the right ascending lumbar vein and right subcostal vein (Latarjet \& Ruiz Liard, 1989; Spalteholz; Williams et al.; Lockhart et al., 1965; Hollinshead, 1966; Gardner et al., 1978).

According to Latarjet \& Ruiz Liard, besides the aforementioned veins, which form a lateral root, there may an inconstant medial root, which may arise from either the IVC or right renal vein. According to Spalteholz, the lateral root only corresponds to the right ascending lumbar vein. However, Testut \& Latarjet (1959), Testut \& Jacob (1964), Gray \& Goss (1988) and Di Dio (1999) state that the origin of the azygos vein is only the continuation of the right ascending lumbar vein. It may, at times begin as a tributary

Doctoral Student at the Universidade Federal de Alagoas, Brazil.

** Substitute Professor of Human Anatomy at the Universidade Estadual de Ciências da Saúde de Alagoas, Brazil.

*** Adjunct Professor of Human Anatomy at the Universidade Federal de Alagoas and Universidade Estadual de Ciências da Saúde de Alagoas; Doctoral Degree in Morphology from the Universidade Federal de São Paulo, Brazil.

***** Assistant Professor of Human Anatomy at the Universidade Federal de Alagoas and Universidade Estadual de Ciências da Saúde de Alagoas; General Surgeon at the General State Hospital, Alagoas, Brazil; Master's Degree in Surgical Gastroenterology from the Universidade Federal de São Paulo, Brazil. 
of the right renal vein or IVC (Gray \& Goss). According to Williams et al. (1995), the azygos vein begins as the lumbar azygos and may arise from the posterior face of the IVC or through a trunk formed by the right ascending lumbar vein and right subcostal vein. According to Lockhart et al., Hollinshead and Gardner et al., the azygos vein is formed by the union of the right ascending lumbar vein and right subcostal vein, but may have direct anastomoses with the IVC. Woodburne states that the azygos vein is formed by three roots: a lateral root that is the junction of the right ascending lumbar vein and right subcostal vein, occurring in 94\% of cases; an intermediate root that is a connection with the IVC and appears in $45 \%$ of cases; and a medial root represented by the fusion of the pre-vertebral veins or communications with the IVC or superior lumbar veins and is found in $30 \%$ of cases. According to Williams et al., when the azygos vein begins as the lumbar azygos, the trunk formed by the right ascending lumbar vein and right subcostal vein is its largest tributary. Hamilton (1982) and Di Dio state that the right subcostal vein is also a tributary and does not participate in the formation of the azygos vein. Considering the variety in the formation of the azygos vein, the aim of the present study was to determine the most common origin of this vein through a series of dissections.

\section{MATERIAL AND METHOD}

The present study received approval from the Ethics Committee of the Universidade Estadual de Ciências da Saúde de Alagoas (UNCISAL, Brazil) under process number 1157/2009. Thirty cadavers male and female, white and non-

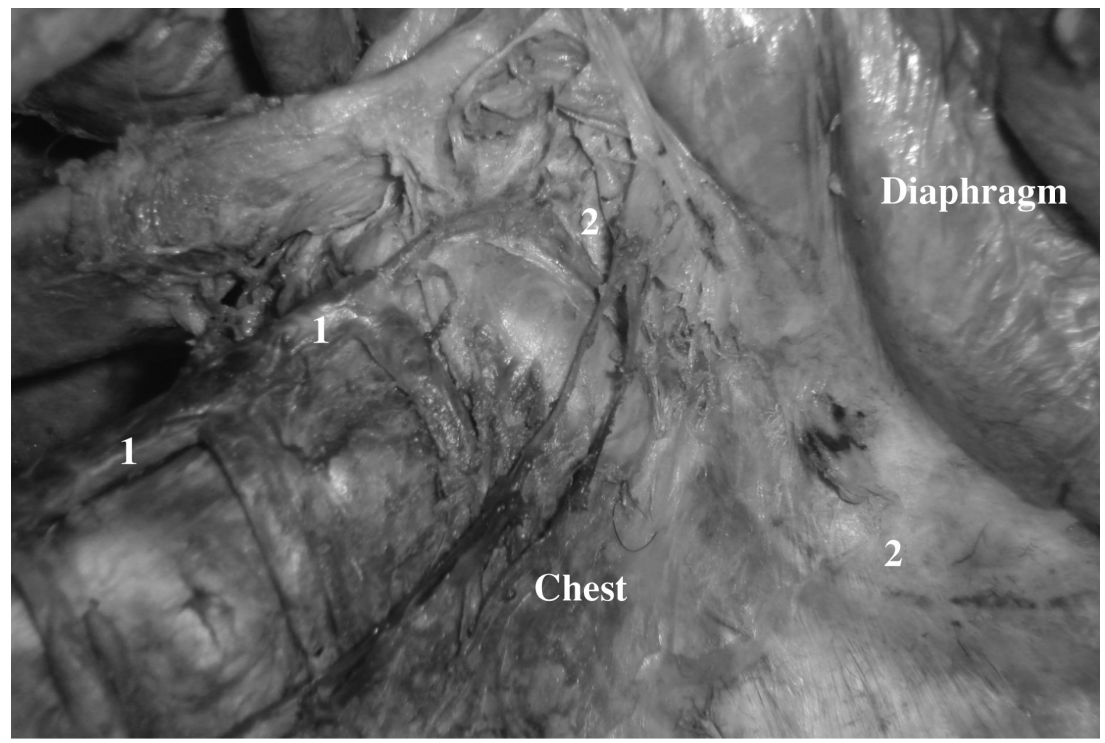

Fig. 1. Azygos vein (1) the continuation of the right subcostal vein (2). white adult individuals of different ages were fixed in 10\% formaldehyde and dissected. All cadavers had an undisclosed clinical death and were donated to UNCISAL. The cadaver was placed in dorsal decubitus and a biacromio-xyphosterno-pubic incision was made to access the thoracic and abdominal cavities. The abdominal viscera were then pushed aside for access of the retroperitoneal space. Dissection was performed, with the identification of the origin of the azygos vein and observation of the structures and formation of this vein. The dissection continued, pushing aside the thoracic visceral and diaphragm in order to follow the azygos vein until it emptied into the superior vena cava.

\section{RESULTS}

The azygos vein demonstrated variable formation involving the participation of eight veins in 11 different combinations, having a single root in $50 \%$ of the cases, two roots in $30 \%$ and three roots in $20 \%$ of cases (Table I).

Table I. Trunk type in formation of azygos vein.

\begin{tabular}{lcc}
\hline \multicolumn{1}{c}{ TRUNK } & CASES & PERCENTAGE \\
\hline Single root & 15 & $50 \%$ \\
Two roots & 09 & $30 \%$ \\
Three roots & 06 & $20 \%$ \\
\hline
\end{tabular}

The most frequent formation originated as the continuation of the right subcostal vein (43.33\%) (Fig.1). The azygos vein was formed by the confluence of the right subcostal and right ascending lumbar vein in three cases (10.00\%); by the right subcostal vein with a contribution from the inferior vena cava (IVC) in three cases $(10.00 \%)$ (Fig. 2); by the right subcostal with a contribution from the IVC and right ascending lumbar vein in three cases $(10.00 \%)$; by the right and left subcostal veins in two cases $(6.66 \%)$; by the right and left subcostal veins and a contribution from the IVC in one case (3.33\%); by the right and left subcostal veins and left accessory renal vein in one case (3.33\%); by the left renal vein in one case $(3.33 \%)$; by the right subcostal and left gonadal veins with a contribution from the IVC in one case $(3.33 \%)$; by the right subcostal and left renal veins in one case $(3.33 \%)$; and composed by the continuation of the 11th posterior intercostal vein in one case (3.33\%) (Table II). 


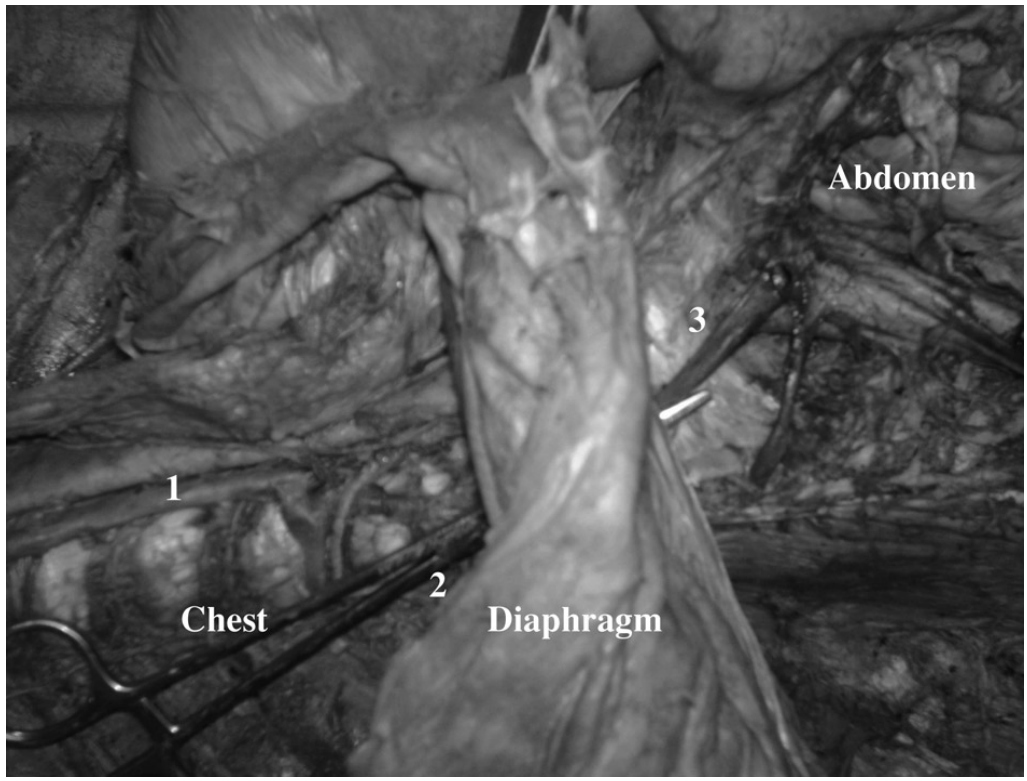

Fig. 2. The azygos (1) vein was formed by the confluence of the right subcostal vein (2) with a contribution from the inferior vena cava (3).

\section{DISCUSSION}

Azygos comes from the Greek A (without) and Zygos (pair) and is applied to all non-paired organs. The azygos vein is a vascular structure responsible for the drainage of blood from the thoracic wall and abdomen (Moore \& Dalley), uniting the upper vena cava to the lower vena cava. This blood vessel may become a collateral pathway between the SVC and IVC. Thus, identifying the variations in its origin is important, since some surgical procedures may require the use of this pathway, as in the case of ligature of the IVC during trauma surgery.

Table II. Formation of azygos vein.

\begin{tabular}{lcc}
\multicolumn{1}{c}{ VEINS } & CASES & PERCENTAGE \\
\hline Right subcostal & 13 & $43.33 \%^{*}$ \\
Right subcostal and right ascending lumbar & 3 & $10.00 \%$ \\
Right subcostal with contribution from IVC & 3 & $10.00 \%$ \\
Right subcostal with contribution from IVC and right ascending lumbar & 3 & $10.00 \%$ \\
Right and left subcostal & 2 & $6.66 \%^{*}$ \\
Right and left subcostal with contribution from IVC & 1 & $3.33 \%^{*}$ \\
Right and left subcostal and left accessory renal & 1 & $3.33 \%^{*}$ \\
Left renal & 1 & $3.33 \%^{*}$ \\
Right subcostal, left gonadal and contribution from IVC & 1 & $3.33 \%^{*}$ \\
Right subcostal and left renal & 1 & $3.33 \%^{*}$ \\
$11^{\text {th }}$ posterior intercostal & 1 & $3.33 \%^{*}$ \\
\hline TOTAL & $\mathbf{3 0}$ & $\mathbf{1 0 0 \%}^{*}$ \\
\hline
\end{tabular}

In the present study, there were 11 cases $(36.66 \%)$ in which either the IVC or one of its tributaries participated in the formation of the azygos vein, as described by previous authors (Lockhart et al.; Hollinshead; Spalteholz; Gardner et al.; Woodburne; Gray \& Goss; Latarjet \& Ruiz Liard; Williams et al.). In eight cases $(26.66 \%)$, this contribution originated directly from the IVC and one such case included an additional root coming from the left gonadal vein. The contribution of the IVC was indirect in the other three cases and came from a left accessory renal vein in one case, from the left renal vein in another and one was a case of a single root stemming from the left renal vein. These findings are in disagreement with Latarjet \& Ruiz Liard, who describe the contribution of the right renal vein.

According to a number of authors, the formation of the azygos vein occurs through the confluence of the right subcostal vein and right ascending lumbar vein (Lockhart et al.; Hollinshead; Spalteholz; Gardner et al.; Latarjet \& Ruiz Liard; Williams et al.). The latter is formed by a vertical anastomosis of the right lumbar veins, which drain the lumbar tegument and muscles, abdominal walls and vertebral venous plexuses. The lumbar veins then move forward, contouring the sides of the vertebrae, and terminate in the IVC (Lockhart et al.; Di Dio). The right subcostal vein originates in the abdomen and drains the region of the 12th rib into the azygos vein. In the present study, there were three cases 
$(10.00 \%)$ with this formation pattern. However, we did not find the right ascending lumbar vein as a vertical anastomosis between the lumbar veins, but rather a contribution from the 1st lumbar vein and occupying the same drainage region suggested in the literature. This finding contrasts that described by other authors (Lockhart et al.; Hollinshead; Spalteholz; Gardner et al.; Latarjet \& Ruiz Liard; Williams et al.).

The right subcostal vein was predominant in the formation of the azygos vein - present in $93.33 \%$ of cases. This is in contrast to descriptions by other authors (Testut \& Latarjet; Testut \& Jacob; Hamilton; Gray \& Goss; Williams et al.; Di Dio), who state that the right subcostal vein is merely a tributary and does not contribute to the formation of the azygos vein. In the present study, the right subcostal vein alone was found to form the azygos vein in $43.33 \%$ of the cases. Moreover, the left subcostal vein participated in the formation of the azygos vein in four cases (13.33\%), which is not described by any of the authors researched.

The results of the present study demonstrate the considerable variety in the formation of the azygos vein, as described in the literature. The only structure with a significant presence in the formation of this vein was the right subcostal vein.

ALVES, E. C.; PORCIÚNCULA JUNIOR, R. W.; MONTE BISPO, R. F.; DE SOUSA-RODRIGUES, C. F. \& DA ROCHA, A. C. Formación de la vena ázigos. Int. J. Morphol., 29(1):140-143, 2011.

RESUMEN: El objetivo del estudio fue verificar cual es la disposición más frecuente del origen de la vena ácigos. Fueron disecados 30 cadáveres de individuos adultos, de ambos sexos, de diferentes grupos étnicos, fijados en formaldehído al 10\%, donados a la Universidade Estadual de Ciencias da Saúde de Alagoas. Se encontraron 11 formaciones diferentes. En 13 casos $(43,33 \%)$ se observó sólo la vena subcostal derecha; en 3 casos (10\%) la vena ácigos estaba formada por la confluencia de las venas subcostal derecha y lumbar ascendente derecha; en 3 casos (10\%) formado por las venas subcostal derecha y una contribución de la vena cava inferior VCI; en 3 casos (10\%) por las venas subcostal derecha y contribución de la VCI y lumbar ascendente derecha; 2 casos $(6,66 \%)$ por las venas subcostales derecha e izquierda; en 1 caso $(3,33 \%)$ por las venas subcostal derecha, izquierda y contribución de la VCI; en 1 caso $(3,33 \%)$ por las venas subcostal derecha e izquierda y renal accesoria izquierda; en 1 caso $(3,33 \%)$ por la vena renal izquierda; en 1 caso $(3,33 \%)$ por las venas subcostal derecha, gonadal izquierda y contribución de la VCI; en 1 caso $(3,33 \%)$ por las venas subcostal derecha y renal izquierda y en 1 caso $(3,33 \%)$ por la continuación de la $11^{\mathrm{a}}$ vena intercostal posterior. Con base en los resultados podemos concluir que la vena subcostal derecha fue la única estructura con presencia significativa en la formación de la vena ácigos.

PALABRAS CLAVE: Vena ácigos; Vena cava inferior; Anatomía.

\section{REFERENCES}

Di Dio, L. J. A. Tratado de Anatomia Aplicada. $1^{\text {a }}$ ed. São Paulo, Póllus, 1999. V. 2

Gardner, E.; Gray, D. J. \& O’Rahilly, R. Anatomía. $4^{\text {a }}$ ed. Rio de Janeiro, Guanabara Koogan, 1978.

Gray, H. \& Goss, C. M. Anatomía. 29a ed. Rio de Janeiro, Guanabara Koogan, 1988.

Hamilton, W. J. Tratado de Anatomía Humana. $2^{\mathrm{a}}$ ed. Rio de Janeiro, Interamericana, 1982.

Hollinshead, W. H. Anatomía Humana. Rosario, Médica, 1966. V. 2

Latarjet, M. \& Ruiz Liard, A Anatomía Humana. $2^{\mathrm{a}}$ ed. São Paulo, Editora do Brasil Ltda., 1989.

Lockhart, R. D.; Hamilton, G. F \& Fyfe, F. W. Anatomía Humana. $1^{a}$ ed. México, Interamericana, 1965.

Moore, K. \& Dalley, A.S. Anatomia Orientada para a Clínica. $4^{\mathrm{a}}$ ed. Rio de Janeiro, Guanabara Koogan, 2001.
Spalteholz, W. Atlas de Anatomía Humana. $3^{\mathrm{a}}$ Ed. Barcelona, Labor, 1967. V. 2

Testut, L. \& Jacob, O. Tratado de Anatomía Topográfica. $8^{\mathrm{a}}$ Ed. Barcelona, Salvat, 1964. V. 2.

Testut, L. \& Latarjet, A. Compendio de Anatomía Descriptiva. $22^{\mathrm{a}}$ ed. Barcelona, Editores, 1959.

Williams, P. L.; Warwick, R.; Dyson, M. \& Bannister, L. H. Anatomía de Gray. 37 ed. Rio de Janeiro, Guanabara Koogan, 1995. V. 1.

Woodburne, R.T. Anatomía Humana. $6^{\mathrm{a}}$ ed. Rio de Janeiro, Editora Guanabara Koogan, 1984.

Correspondence to:

Prof. Dr. Célio Fernando de Sousa Rodrigues

Disciplina de Anatomia Humana

Universidade Estadual de Ciências da Saúde de Alagoas UNCISAL

Rua Jorge de Lima, 113

CEP: $57010-300$

Trapiche, Maceió-AL,

BRAZIL

Received: 18-10-2010

Accepted: 22-12-2010 